University of Nebraska - Lincoln

DigitalCommons@University of Nebraska - Lincoln

Public Health Resources

Public Health Resources

2011

HLA/KIR Restraint of HIV: Surviving the Fittest

Arman A. Bashirova

National Institutes of Health, Arman.Bashirova@nih.gov

Rasmi Thomas

National Institiutes of Health, thomasrasmi@mail.nih.gov

Mary Carrington

National Institutes of Health, carringm@mail.nih.gov

Follow this and additional works at: https://digitalcommons.unl.edu/publichealthresources

Part of the Public Health Commons

Bashirova, Arman A.; Thomas, Rasmi; and Carrington, Mary, "HLA/KIR Restraint of HIV: Surviving the Fittest" (2011). Public Health Resources. 125.

https://digitalcommons.unl.edu/publichealthresources/125

This Article is brought to you for free and open access by the Public Health Resources at DigitalCommons@University of Nebraska - Lincoln. It has been accepted for inclusion in Public Health Resources by an authorized administrator of DigitalCommons@University of Nebraska - Lincoln. 


\title{
HLA/KIR Restraint of HIV: Surviving the Fittest
}

\author{
Arman A. Bashirova, Rasmi Thomas, \\ and Mary Carrington
}

Ragon Institute of Massachusetts General Hospital, MIT, and Harvard University, Boston, Massachusetts 02129; Cancer and Inflammation Program, Laboratory of Experimental Immunology, SAIC-Frederick, Inc., NCI-Frederick, Frederick, Maryland 21702;

email: Arman.Bashirova@nih.gov, thomasrasmi@mail.nih.gov, carringm@mail.nih.gov

Annu. Rev. Immunol. 2011. 29:295-317

First published online as a Review in Advance on January 3, 2011

The Annual Review of Immunology is online at immunol.annualreviews.org

This article's doi:

10.1146/annurev-immunol-031210-101332

Copyright (c) 2011 by Annual Reviews.

All rights reserved

0732-0582/11/0423-0295\$20.00

\section{Keywords}

CTL, escape mutations, NK cells, GWAS, host genetics, viral evolution

\begin{abstract}
Multiple epidemiological studies have demonstrated associations between the human leukocyte antigen $(H L A)$ loci and human immunodeficiency virus (HIV) disease, and more recently the killer cell immunoglobulin-like (KIR) locus has been implicated in differential responses to the virus. Genome-wide association studies have convincingly shown that the $H L A$ class I locus is the most significant host genetic contributor to the variation in HIV control, underscoring a central role for CD8 $\mathrm{T}$ cells in resistance to the virus. However, both genetic and functional data indicate that part of the $H L A$ effect on HIV is due to interactions between $K I R$ and $H L A$ genes, also implicating natural killer cells in defense against viral infection and viral expansion prior to initiation of an adaptive response. We review the $H L A$ and KIR associations with HIV disease and the progress that has been made in understanding the mechanisms that explain these associations.
\end{abstract}




\section{INTRODUCTION}

HLA: human leukocyte antigen

KIR: killer cell immunoglobulin-like receptor

HIV: human immunodeficiency virus

GWAS: genome-wide association study

SIV: simian immunodeficiency virus
The human leukocyte antigen (HLA) and killer cell immunoglobulin-like (KIR) molecules are encoded by two of the most diverse gene families in the human genome. Given the involvement of these molecules in fundamental immune processes such as antigen presentation to $\mathrm{T}$ cells and regulation of natural killer (NK) cell responses, it is no surprise that the extreme diversity characterizing the $H L A$ and KIR loci impacts viral pathogenesis differentially across individuals. $\mathrm{HIV}$ is now the most thoroughly studied virus across many disciplines, including viral/host immunogenetic relationships. As was suspected based on earlier studies, the central importance of the $H L A$ class I locus in the differential control of HIV that is seen across patients was borne out in the first genome-wide association studies (GWAS), underscoring the exclusive role of this locus in the whole genome context.

HIV remains a global health problem, with more than 30 million people infected worldwide, concentrated most severely in subSaharan Africa. Nearly three decades of intensive research have now led to substantial progress in understanding HIV pathogenesis and immunity to the virus. The availability of a model exploiting simian immunodeficiency virus (SIV) in nonhuman primates has advanced the field. Improved access to antiretroviral therapy (ART) has decreased mortality and morbidity of HIV infection within those countries where the drugs are available. However, HIV vaccine development remains extremely challenging, with no clear success in humans.

The diversity of clinical outcomes after HIV infection is broad, ranging from progression to acquired immunodeficiency syndrome (AIDS) within a year of seroconversion to the control of $\mathrm{HIV}$ without drugs for more than two decades. A small fraction of individuals are resistant to HIV infection, even upon repeated exposure. The diversity of responses to HIV has to do with viral, host, and environmental variability, all of which must eventually be meshed to generate a predictive algorithm for outcome after
HIV exposure. There is now abundant information regarding host genetic variation and its consequence on outcome to HIV infection, particularly at the $H L A$ class I loci and, to a lesser extent, the KIR locus. In this review, we focus on HLA and KIR involvement in HIV/AIDS as a model for viral diseases in general, summarizing the influence that variation at these loci has on $\mathrm{HIV}-1$ pathogenesis.

\section{OVERVIEW OF HLA AND KIR GENETICS AND FUNCTIONS}

HLA class I and class II molecules present antigenic peptides on the surface of cells to CD8 and CD4 T cells, respectively. CD8 T cells kill infected cells through recognition of viral epitopes or self stress peptides (i.e., intracellularly derived peptides) presented in the context of HLA class I on the target cell surface. CD4 T cells recognize antigens that are primarily extracellularly derived and in the context of HLA class II, resulting in production of cytokines that help other immune cells to respond. Besides directing CD8 $\mathrm{T}$ cell activity, class I molecules also regulate NK cell activity via interactions with NK cell receptors, including KIRs.

The HLA class I and class II molecules are encoded by genes located within the human major histocompatibility complex $(M H C)$, which encompasses $\sim 4 \mathrm{Mb}$ on chromosome $6 \mathrm{p} 21.3$

(Figure 1). It is one of the most gene-dense regions within the human genome, containing 45 $H L A$-like genes and 208 non-HLA genes (1). The HLA-like genes share both sequence and structural homology, and many have immunological functions. The $H L A$ class I region contains three classical class I genes $(H L A-A,-B$, and $-C$ ) that are expressed by all nucleated cells and encode transplantation antigens (2). The classical class II genes are $H L A-D P,-D Q$, and $-D R$, and their products are expressed on the surface of antigen-presenting cells and B cells.

The defining feature of $H L A$ class I and class II genes is their extreme polymorphism. Variation across $H L A$ alleles is concentrated within the regions encoding sites that bind peptides 


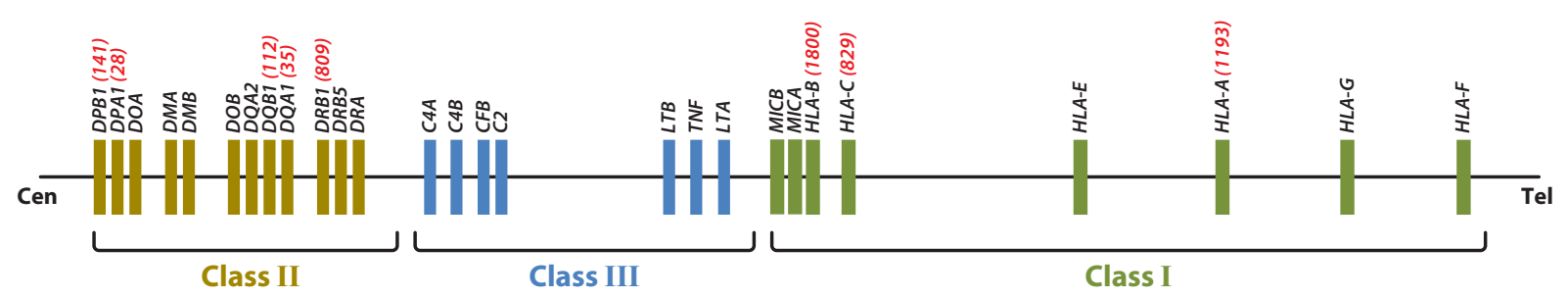

Figure 1

The genetic map of the human $M H C$. A subset of genes within the 4 Mb region of the $M H C$ is shown. Numbers of alleles for the classical class I and class II genes (based on the information from the IMGT/HLA database, http://www.ebi.ac.uk/imgt/hla) are depicted in red.

and the $\mathrm{T}$ cell receptor. $H L A-B$ is the most diverse gene in the human genome, with 1,800 alleles described in the IMGT/HLA database (http://www.ebi.ac.uk/imgt/hla). The current focus on $H L A$ in terms of its effects on disease susceptibility/pathogenesis is the variation in the coding regions of the genes. Evidence suggests that even a single amino acid change can influence structural and functional properties of HLA antigens and can influence susceptibility to HIV disease (3). Studies are now beginning to focus on variants in noncoding regions of the HLA genes, which may affect the level of transcription, translation, and splicing.

Extreme polymorphism of $H L A$ genes parallels the diversity of the functionally related $K I R$ genes, which encode receptors that regulate NK cell function. NK cells are key mediators of innate immunity that kill aberrant target cells or secrete cytokines without prior exposure to the target. NK cell activity is controlled by a battery of inhibitory and activating receptors, most of which recognize HLA class I- or class I-like molecules (4). KIRs are mainly expressed on $\mathrm{CD} 56^{\mathrm{dim}} \mathrm{CD} 16^{\text {pos }} \mathrm{NK}$ cells, which constitute the bulk of peripheral blood NK cells and have high cytotoxic potential. Tolerance to self can be generated through KIRs that inhibit NK cell activity upon recognition of normal levels of class I expression, whereas activation of NK cells, potentially involving activating KIRs, may occur when class I expression is downregulated. Extensive genetic polymorphism of the $K I R$ and $H L A$ class I loci is likely to influence variability in functional capacities of NK cells across individuals.

$K I R$ genes are arranged in a head-to-tail cluster on human chromosome 19q13.4 spanning approximately 100-200 kb (5). KIR2DL and KIR3DL genes encode molecules with inhibitory capacity (with the exception of KIR2DL4, which may have both inhibitory and activation potential), whereas KIR2DS and KIR3DS encode activating receptors. Substantial gene content and allelic variation are observed in humans (6). There are two basic groups of KIR haplotypes, termed A and $\mathrm{B}$ (Figure 2). Haplotype A consists of nine genes and encodes predominantly inhibitory receptors, whereas the B haplotypes represent a diverse group of haplotypes based on gene content and contain more activating KIRs compared with haplotype A. Another specific feature of the KIR locus is that expression of KIR genes is variegated and clonally restricted (7). Multiple alleles exist for each KIR gene, and alleles of a given $K I R$ gene can vary in expression level or functional capacity. Despite a great deal of variation in gene content across haplotypes, almost all individuals possess four framework genes: KIR3DL3, KIR3DP1, KIR2DL4, and KIR3DL2. In addition, the vast majority of humans possess loci encoding KIR2DL1, KIR2DL2/2DL3, and KIR3DL1/3DS1. Inhibitory receptors encoded by these three loci are probably the major players in KIR-mediated NK cell recognition of HLA-B (KIR3DL1) and HLA-C (KIR2DL1，KIR2DL2，KIR2DL3) molecules on target cells. 


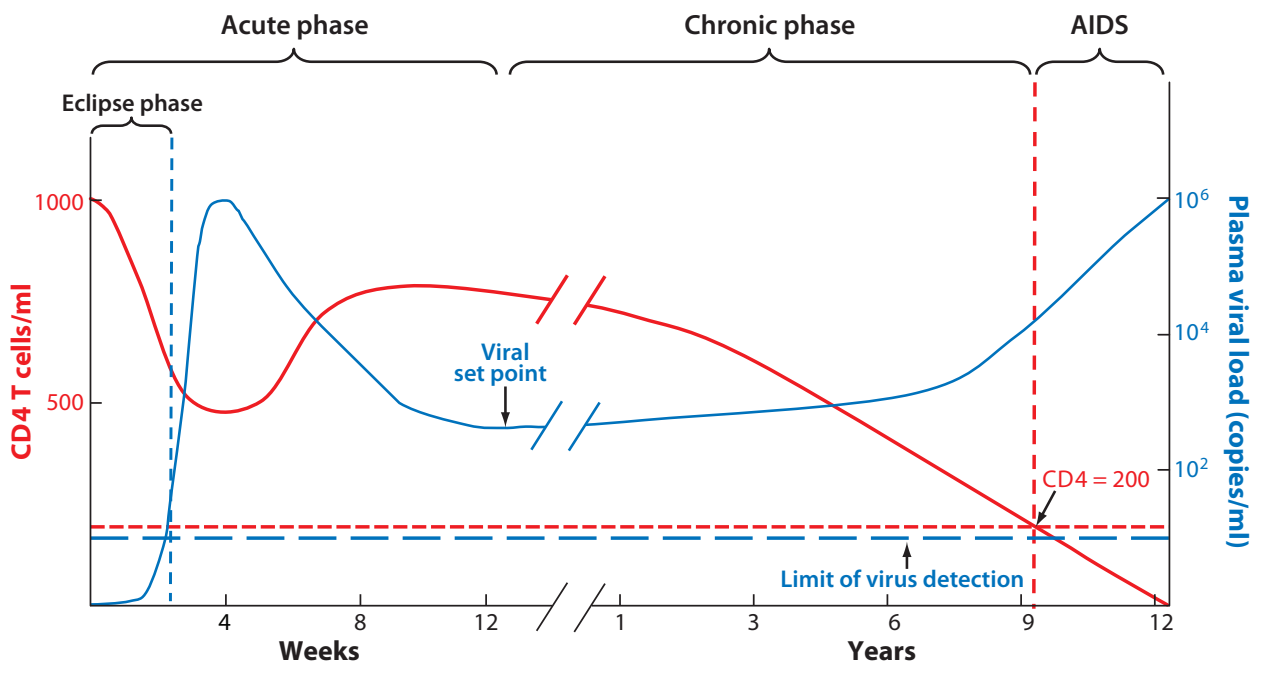

Figure 3

Dynamics of peripheral blood CD4 T cell counts and plasma viral load during a typical course of HIV infection. The three major phases of infection are shown: acute, chronic, and AIDS. The eclipse phase is the initial stage of the acute infection before systemic viral dissemination. The acute phase is characterized by flu-like symptoms and a peak viral load, followed by a drop to a set point level. During the asymptomatic chronic phase, viral load gradually increases while CD4 T cell counts gradually decline to the level of 200 cells/ml of blood, a point defining AIDS onset.

asymptomatic chronic phase can last for years, during which viral load gradually increases and CD4 T cell counts decrease to the point where the immune system can no longer protect the body from opportunistic infections or certain cancers. Recent findings point to the importance of events within the gastrointestinal tract for HIV/SIV pathogenesis (16). Massive depletion of CD4 $\mathrm{T}$ cells and structural damage occur in the gastrointestinal mucosa during the acute phase of HIV/SIV infection. Increased mucosal permeability allows microbial translocation, which leads to chronic immune activation, the apparent driving force of immunodeficiency.

A minority of HIV-1-infected individuals $(\sim 5-15 \%)$ called long-term nonprogressors (LTNP) maintain normal CD4 T cell counts and remain AIDS-free in the absence of ART (17). It is well established that the level of set point viremia impacts disease progression (18, 19). Indeed, the vast majority of LTNP exhibit low-level viremia, some of them below 50 copies of the virus per $\mathrm{ml}$ of plasma. These elite controllers (EC) have been invaluable in studies of immunological correlates of virus control.

\section{HLA AND KIR IN HIV IMMUNITY}

\section{HLA Class I and CD8 T Cells}

The era of studies investigating HIV-specific CD8 cytotoxic T lymphocytes (CTLs) from the blood of infected patients began in the late 1980s (20-22), opening a floodgate of CTL intelligence. CD8 $\mathrm{T}$ cell activity was shown to temporarily correlate with initial control of acute viremia $(23,24)$, and depletion of the CD8 T cells was linked to a loss of viral control in SIV infection (25, 26). Many HLA class I-restricted epitopes recognized by CD8 T cells were identified (http://www.hiv.lanl.gov) and characterized for their ability to cripple the virus (2730). Studies of $H L A$ allelic effects on various outcomes to HIV infection were published (see following sections), and strong links between specific viral mutations and a given $H L A$ class I allele were uncovered (31-33).
Long-term nonprogressors (LTNP): a minor subset of HIV-infected patients who do not progress to AIDS in the absence of drug therapy

Elite controllers (EC): a subset of LTNP who maintain their viral load below the detection limit of commercial assays $(50$ copies per $\mathrm{ml}$ of plasma) 
Escape mutations: mutations in the viral sequences that arise due to selective pressure from the immune response

Gag: an HIV polyprotein precursor that is cleaved into four proteins, p17 matrix, p24 capsid, p7 nucleocapsid, and p6. Gag p24 contains four B*57-restricted immunodominant epitopes, TW10, KF11, IW9, QW9, and a B*27-restricted immunodominant epitope, KK10. An abundance of Gag in viral particles makes this protein an important antigen
There is strong evidence that CD8 T cells exert extreme selection pressure on HIV sequences over the course of infection $(27,34$ 43), whether beneficial to the host or not. Viral escape mutations arising within the HLA class I-restricted CD8 $\mathrm{T}$ cell epitopes can function to disrupt binding of a viral peptide to HLA class I or impair recognition by the $\mathrm{T}$ cell receptor. Mutation in regions immediately flanking the epitope may affect antigen processing, facilitating escape from CD8 $\mathrm{T}$ cell response (44). About two-thirds of all nonenvelope viral mutations detected in the chronic phase are attributed to CD8 $\mathrm{T}$ cell responses in HIV-1infected patients, indicating a dominant influence of this arm of immunity on viral evolution (34). However, owing to apparent restrictions on viral fitness, the virus can afford only certain escape pathways, which can be predicted to some extent by the patient's $H L A$ genotype (34, 45). Transmission of HIV containing a given escape mutation to a new recipient may result in reversion of the mutation, depending on the fitness cost and the recipient's immune response $(27,46)$. Progress in sequencing technologies, availability of large cohorts of HIV-1-infected individuals, and new statistical tools have enabled detection of HIV-1 evolution driven by CD8 T cell pressure at the population level (31$33,47,48)$.

The dynamics of the CD8 $\mathrm{T}$ cell response are complex, with significant qualitative and quantitative changes over the course of HIV infection. Acute CD8 T cell responses typically target a small number of epitopes, and responses to these specific epitopes rapidly decline after reaching a peak, which can be attributed to a decrease in viral load, viral escape, and/or effector cell exhaustion (43, 49). During the chronic phase of infection, immunodominance patterns generally change (50) and the CD8 $\mathrm{T}$ cell response shifts to a broader epitope recognition pattern (51). Immunodominant CD8 $\mathrm{T}$ cell responses that make a larger relative contribution to the total response developed during primary infection associate with a lower viral set point, and preservation of these responses in the chronic phase associates with slower CD4 decline (50).

Much effort has been directed toward identification of unique features of $\mathrm{HIV}$-specific CD8 T cell activity from LTNP and EC, in particular. Although the breadth and magnitude of overall HIV-specific CD8 T cell responses do not seem to correlate with HIV control in chronically infected individuals $(51,52), \mathrm{CD} 8$ responses directed against $\mathrm{Gag}$ were found to be critical for viral suppression in chronic infection (51-56). This can be explained by the relatively conserved nature of this structural protein and/or by the overall abundance of the Gag protein in virus particles that allows rapid processing and presentation of Gag peptides to CD8 $\mathrm{T}$ cells (57). In addition, HIV-specific CD8 T cells from EC were more potent compared with noncontrollers according to several parameters, including the ability to produce multiple cytokines and chemokines, proliferate, and exert cytotoxicity (58-63). Whether this is a cause for or an effect of EC status requires further consideration.

\section{HLA Class II and CD4 T Cells}

The key role of CD4 $\mathrm{T}$ cells in immune responses is underscored by the devastating consequences of CD4 $\mathrm{T}$ cell depletion in HIV infection. Based on animal models of chronic viral infections, investigators have suggested that CD4 $\mathrm{T}$ cells are necessary for the maintenance of stable CD8 T cell memory, although they are not essential in primary CD8 $\mathrm{T}$ cell responses (64-66). CD4 T cells are the principal targets for HIV, and the virus preferentially infects HIV-specific CD4 T cells (67). Although most HIV-specific CD4 T cells are not infected (67) and may contribute to antiviral response, there is an impairment in proliferative capacity of these cells in viremic patients (68-70). In contrast, preservation of virus-specific CD4 $\mathrm{T}$ cells that can proliferate and produce IL-2, characteristic of central memory cells, is associated with low viral load in both treated and untreated patients (68-71). Besides the 
traditional helper function, virus-specific CD4 $\mathrm{T}$ cells can exert direct cytotoxicity against HIV - and SIV-infected cells (72-74). In addition, induction of a virus-specific CD4 $\mathrm{T}$ cell response has been documented in relatively successful vaccinations against SIV (75) and HIV (76).

Although $H L A$ class II genetic associations with HIV disease outcomes have been reported, the findings are not nearly as convincing as those for class I. This could be due to the outcomes tested, such as viral load, which largely depends on class I-restricted CD8 responses. In addition, HLA class II restriction is not as well defined as that for class I for several reasons: Class II epitopes are harder to pinpoint because they vary in length to a greater extent than do class I, class II tetramers are difficult to produce relative to class I tetramers, there are lower frequencies of HIV-specific CD4 T cells compared with CD8 T cells (77), and CD4 T cells are depleted over the course of infection. Alternatively, the promiscuity in antigen presentation across class II allotypes may render alleles roughly equal in terms of HIV restriction, which results in the absence of clear genetic effects of class II variation $(78,79)$.

CD4 T cell responses have been systematically analyzed in chronically infected patients to map epitopes across the clade B (78) and clade C (80) viral proteomes. There was a significant inverse correlation between the presence of the CD4 response to Gag and viral load in untreated clade $C$ patients (80). Recent data using an expanded data set of the same cohort (80) indicated that individuals expressing DRB1*1303, an allele significantly associated with low viral load, have fewer Gag-specific responses compared with all other patients (B. Julg, personal communication). These seemingly inconsistent results can probably be resolved by distinguishing cause from effect when interpreting data that involve effector cell responses from $\mathrm{HIV}$-infected patients.

The difficulties in studying CD4 $\mathrm{T}$ cell responses in HIV infection in general may explain the absence of any clear effect of $H L A$ class II polymorphism on HIV disease.
Alternatively, class II polymorphism may not have any measurable effect on disease pathogenesis if would-be beneficial responses conferred by certain alleles occur too late after infection. Further attempts to define and distinguish CD4 $\mathrm{T}$ cell responses by comparisons of their functions across individuals with distinct class II allotypes may be pivotal in the design of an effective vaccine where the protective responses are generated prior to infection.

\section{HLA Class I, KIR, and NK Cells}

Similar to other viruses, HIV downregulates expression of class I molecules on the surface of infected cells to escape from CD8 $\mathrm{T}$ cell lysis (81). This renders the cells potential targets for NK cells. Notably, HIV downregulates HLA-A and HLA-B, whereas HLA-C expression is preserved (82). Thus, NK cell receptors that bind HLA-C might be preferentially important in recognition of infected cells.

Early HIV infection is characterized by expansion of blood NK cells, which precedes the expansion of CD8 T cells (83). This expansion can be influenced by a $H L A$ class I genotype, as investigators have shown that the frequencies of NK cells expressing KIR3DS1 and, to a lesser extent, KIR3DL1 are specifically increased during acute HIV-1 infection in the presence of HLA-B Bw4-80I (84). Selected expansion of NK cell subsets may be beneficial to the host because an immediate, aggressive response to HIV may prevent an established infection.

Several studies have shown that NK cells isolated from viremic patients are impaired in their function (85-87). One reason for such impairment is the expansion of a $\mathrm{CD} 56^{-} \mathrm{CD} 16^{+}$ subset of NK cells that is present at low levels in healthy individuals and in HIV-infected patients with suppressed virus replication $(86,88$, 89). These abnormal NK cells express KIRs, and their defective lytic capability has been attributed in part to elevated expression of inhibitory KIR2DL2/2DL3 receptors that bind to HLA-C (88).

Because of the nature of NK cell regulation and HIV infection, the effect of inhibitory and 
Linkage

disequilibrium (LD):

nonrandom

association between

alleles of different

linked loci

Balancing selection: natural selection that acts to maintain multiple alleles of a gene either by favoring heterozygotes (overdominance) or by favoring rare alleles (frequency dependent selection) activating signaling is complex. Although NK cell activation may result in the killing of infected cells, inhibitory signaling is required for NK cell education (13) and may also diminish immune activation, a characteristic of disease progression (16).

\section{HLA POLYMORPHISM AND HIV/AIDS}

The primary influence of variation within the $H L A$ class I loci on the level of viral load and AIDS progression relative to all other single human genetic variants has now been set in stone by the several GWAS published to date (90-93). The most significant variants identified include a single nucleotide polymorphism (SNP) in the HCP5 gene, which is in virtually perfect linkage disequilibrium (LD) with $H L A-B^{*} 5701$ in Caucasians (90-92, 94), two variants located $35 \mathrm{~kb}$ upstream of the $H L A-C$ locus (90-92, 94), and an intronic variant in the $H L A-B$ gene linked to $H L A-B^{*} 5703$ in African Americans (93). The genome-wide significance of SNPs linked to $B^{*} 57$ alleles supports previous genetic and functional data on the importance of the $H L A-B$ locus in HIV pathogenesis, particularly strong protection conferred by $B^{*} 57$ alleles. These studies also provide novel evidence for a principal role for the $H L A-C$ locus in HIV disease control. Of note, no class II associations were evident from the GWAS, and the $H L A-A$ locus does not show a clear effect (91).

Individual HLA alleles and alleles grouped together based on a given hypothesis have been associated with HIV outcomes. One of the most interesting recent developments in this regard is the move to investigate effects of noncoding regions, which seem to contain riches that are only beginning to be unearthed.

\section{$H L A$ Heterozygote and/or Rare Allele Advantage?}

Properties of the $M H C$ locus have set it apart from other genes. HLA genes contain many sequence variants, similar to microsatellites, immunoglobulin $(I g)$ genes, and $\mathrm{T}$ cell receptors $(T C R)$, but unlike microsatellites, HLA genes do not have high mutation rates (95), nor are there specialized mechanisms for somatic diversification as are found with $I g$ and TCR genes. In addition, the polymorphic variation at the $M H C$ class I and II loci is older than that in any other known locus, as determined by both the time needed to accumulate the observed allelic divergencies and the observation that allelic variants similar to those of humans are found in apes. In multiple species, the class I and II allelic frequencies are more evenly distributed than expected by chance, with an excess of intermediate frequency alleles. These diverse and peculiar properties of class I and II genes are well explained by the existence of balancing selection acting on these loci. The primary function of these MHC molecules is to present foreign antigens to elicit $\mathrm{T}$ cell responses, so a pathogen-driven form of balancing selection is often invoked. For many reasons, however, commensal organisms of the gut and other tissues may be a more likely driving force of $M H C$ balancing selection because they have a long symbiotic relationship with their host but are occasionally pathogenic and need to be constantly kept in check (96).

Balancing selection itself can occur in one of two forms, either heterozygote advantage (overdominant selection) or rare allele advantage (frequency-dependent selection). Heterozygote advantage contends that in general, individuals who are heterozygous at the HLA locus will present a broader repertoire of antigenic peptides to $\mathrm{T}$ cells than will homozygotes, challenging the pathogen to escape from a greater variety of CTL responses. Rare allele advantage is based on the premise that the most frequent form of a pathogen circulating in a given population is more likely to have escaped from common $H L A$ alleles, making the low frequency allotypes advantageous for the host.

The relative contributions of each of these models have been subject to debate (97). HIV epidemiological data have been applied to test both models. Data supporting a heterozygote 
advantage against HIV showed an increasingly protective effect, in terms of disease progression, with greater numbers of distinct $H L A$ class I alleles $(98,99)$. Recent work on cynomolgus monkeys demonstrated lower chronic SIV viral loads by nearly two logs in class I heterozygous as opposed to homozygous animals (100). Based on viral sequences, heterozygous monkeys appear to exert greater overall CD8 T cell pressure on the virus compared with that in homozygous animals. The breadth of Gag-specific CD8 $\mathrm{T}$ cell responses to HIV correlates with lower viral load $(54,55)$, which may be due in part to a greater number of distinct class I alleles in heterozygous patients.

In support of a rare allele advantage, investigators have demonstrated a positive correlation between viral load and the frequency of $H L A$ class I supertypes (101). As the model suggests, such a correlation may be due to viral adaptation at a population level. Indeed, a recent study in nine cohorts representing five continents demonstrated a strong positive correlation between epitope mutations and frequencies of restricting $H L A$ class I alleles (47).

Based on HIV genetic epidemiologic data, it is difficult to clearly distinguish heterozygous advantage from rare allele advantage because low frequency alleles are much more likely to occur in the heterozygous form. It is plausible that both heterozygote advantage and rare allele advantage apply to HIV-infected individuals. Despite all theoretical support of evolutionary models, however, HIV is unlikely to have any permanent effect on $H L A$ allelic frequency distributions. But the effect of HLA on HIV evolution is evident in a geographic-specific sense.

\section{$H L A-B$ Locus: The Queen Bee of HIV Host Genetics}

The $H L A-B$ locus is the most polymorphic of all the $H L A$ loci (102). Perhaps related to its extensive diversity, it also shows the strongest and most consistent genetic effects on outcomes of HIV infection relative to the other HLA class I and class II genes (103). Functional data from a large study of clade $\mathrm{C}$ patients showed that most CD8 T cell responses to HIV were HLA$B$ restricted and that variation in viral load was predominantly associated with variation at the $H L A-B$ locus (104), nicely correlating the genetic data with functional analysis and emphasizing the importance of $H L A-B$ polymorphism in determining the outcome of HIV infection.

The $H L A-B^{*} 57$ allele tops all others in terms of its effect on HIV, and this effect is protective both in terms of viral load control and delayed progression to AIDS (104-108). HLA$B^{*} 57$ carriers are overrepresented among EC $(105,108)$ and present symptoms of acute HIV1 infection less frequently compared with noncarriers (109). The exclusive status of $B^{*} 57$ in HIV pathogenesis relative to SNPs located throughout the rest of the genome is being repeatedly observed with each additional GWAS report (90-94). An early genetic effect of $B^{*} 57$ after HIV infection was originally indicated by survival analyses, where $B^{*} 57$ protection was most apparent for time to CD4<200 (the earliest outcome available for survival analysis in our cohorts), as opposed to an AIDS-defining illness or death (106). The effect of $B^{*} 57$ has now been shown for set point viral load (92), an outcome that occurs much earlier than CD $4<200$.

Several factors contributing to the mechanism of $B^{*} 57$ protection have been suggested. B*57 restricts three or four immunodominant epitopes located in conserved regions of Gag, and escape mutations within these targeted epitopes are commonly observed in viruses isolated from $B^{*} 57$-positive individuals $(27,36,46,110)$. Reduced viral fitness of the escape variants, verified by both in vitro assays and in vivo reversions $(27-29,36)$, may explain in part the $B^{*} 57$ protective role. A recent study suggests a dual mechanism for $\mathrm{B}^{*} 57$-related viral control involving both viral fitness loss and induction of CD8 $\mathrm{T}$ cell response against escaped epitopes (30).

An important feature of $\mathrm{B}^{*} 57$ is its immunodominance in acute CD8 $\mathrm{T}$ cell responses, which appears to be greater than that of any other HLA allotype, with the most frequently targeted epitope being Gag TW10 (111). Mathematical models of T cell 
selection in the thymus support the concept of B*57 immunodominance by predicting a relatively large pool of $B^{*} 57$-restricted naive T cells specific for HIV compared with cells restricted by other class I allotypes (112). These models also implicate greater cross-reactivity of $\mathrm{B}^{*} 57$ restricted CD8 $\mathrm{T}$ cells to mutating epitopes. Dominant, cross-reactive targeting of Gag epitopes by B*57-restricted CD8 T cells may be important in control of viral replication because Gag can be presented by infected cells early postinfection, even before viral integration and protein synthesis (57). Targeting multiple Gag epitopes by B*57-restricted CTLs is additionally advantageous to the host because it complicates viral escape from the total CD8 response.

$H L A-B^{*} 27$ also provides protection in terms of viral control and AIDS progression (106$108,113,114)$. The mechanism of $\mathrm{B}^{*} 27$ protection may be somewhat similar to $\mathrm{B}^{*} 57$, as it involves induction of an immunodominant CD8 response against a highly conserved Gag epitope $(40,111,115)$, coming in second after B*57 in the hierarchy of immunodominance during acute phase (111). Despite certain similarities to $\mathrm{B}^{*} 57, \mathrm{~B}^{*} 27$ protection has distinct features. Unlike the B*57-restricted CD8 response, which targets up to four Gag epitopes, $\mathrm{B}^{*} 27$ restriction is focused on a single epitope, KK10. Under B*27-restricted pressure, the virus undergoes a complex pattern of mutations that result eventually in a fully escaped virus with wild-type levels of replicative capacity (116). Development of this escape profile results in rapid disease progression $(40,115,117)$. The escape is typically conferred by three mutations, S173A/R264K/L268M (116). Delay in the development of this variant is thought to be due to impaired replicative capacity of viruses that bear the individual mutations S173A or R264K (116). B*27 escape mutations seem to be stable upon transmission to $\mathrm{B}^{*} 27$-negative subjects, in contrast to $\mathrm{B}^{*} 57$ escape mutations, which often revert back in HLA-mismatched individuals (118). The $\mathrm{B}^{*} 27$ peptide-binding specificity is shared, remarkably, with Mamu$\mathrm{B}^{*} 08$, a macaque MHC class I allotype that confers protection in SIV infection (119). Most
Mamu-B*08-restricted SIV epitopes and B*27restricted $\mathrm{HIV}-1$ epitopes possess a dibasic motif at the $\mathrm{N}$ terminus (RK or KK), a feature that makes these peptides resistant to peptidases and therefore more stable in the cytosol. Unlike $B * 27$, however, protection conferred by MamuB*08 does not involve immunodominant targeting of a Gag epitope and delayed viral escape: The Mamu-B*08-restricted YL9 epitope (ana$\log$ of HIV-1 KK10) is rarely targeted in SIVinfected Mamu-B*08-positive animals (119).

$H L A-B^{*} 35$ alleles associate with susceptibility to AIDS across multiple studies (98, 120-122). B*35-restricted CD8 T cells rarely recognize Gag in primary infection (123). Gao et al. (3) identified a subset of alleles, termed $B^{*} 35-P x$, that associate most strongly with the susceptible effect. The $\mathrm{B} * 35-\mathrm{Px}$ allotypes (B*3502, B*3503, B*3504, B*5301) prefer to bind peptides with small hydrophobic residues at position $9(2,124)$, as opposed to the $\mathrm{B} * 35$ PY allotypes (B*3501 and B*3508), which favor binding peptides with tyrosine at the same position $(125,126)$. Perhaps B*35-Px presents peptides that are distinct from and less protective than those presented by B35-PY (for example, PY9 Gag epitope), although in vitro data do not support clear differences in peptide-binding specificity between $\mathrm{B}^{*} 35-\mathrm{Px}$ and $\mathrm{B} * 35-\mathrm{PY}$ $(123,127)$. Still, some disparity in correlations of CD8 $\mathrm{T}$ cell targeting of Gag and viral loads were detected between the two $\mathrm{B}^{*} 35$ groups (128). A novel view of the $B^{*} 35$ susceptibility mechanism involving dendritic cells (DCs) was suggested recently (127) based on the observation that $\mathrm{B}^{*} 35$-Px binds to the Ig-like transcript 4 (ILT4), an inhibitory receptor expressed on DCs, with greater affinity than does B*35-PY in the presence of the same HIV-1 peptides. This may result in more prominent DC dysfunction in $\mathrm{B}^{*} 35$-Px-positive individuals, thereby accelerating disease progression (127).

\section{$H L A-C$ : The Dark Horse of HIV Host Genetics}

A primary role for HLA-C as a CTL restriction factor has been questioned because of its limited 
polymorphism and its low level of cell surface expression compared with its HLA-A and -B counterparts (129). It is now known that every HLA-C allotype is a ligand for inhibitory KIR and that virtually every individual possesses the $K I R$ genes that encode receptors for HLA-C (130), implicating this locus as the most important in terms of KIR regulation of NK cell activity. Indeed, an effect of certain $H L A-C$ genotypes in combination with KIR2DL3 was implicated with $\mathrm{HCV}$ clearance previously (131). However, in contrast to $H L A-B$ alleles, neither individual $H L A-C$ alleles nor combinations of $H L A-C$ groups with $K I R$ have shown a consistent effect with HIV pathogenesis (apart from those that are more readily explained by $\mathrm{LD}$ with $H L A-B$ alleles). HLA-C is the only classical HLA class I molecule that is not downregulated by HIV Nef (82), which further points to a functional distinction of this locus compared with HLA-A and -B. Recently, a grouping of $H L A-C$ alleles marked by a SNP upstream of the locus was shown to have the second most significant effect on HIV viral load genome-wide, tapping into a previously undiscovered role for $H L A-C$ in control of the virus.

This variant, located $35 \mathrm{~kb}$ upstream of the $H L A-C$ gene $(-35 C / T)$, was identified as the second strongest hit associated with control of HIV-1 viral load in European
Americans (92), and this region was implicated again in subsequent GWAS studies (90, 91, 94). It was suggested, based on $B$ cell line mRNA data, that that the effect of the -35 variant may be due to differences in $H L A-C$ gene expression $(92,132)$. To identify a potential mechanism for the protection conferred by this variant, we examined HLA-C expression on CD3 $\mathrm{T}$ lymphocytes of normal donors using an HLA-C-specific monoclonal antibody and showed that the $-35 C C$ genotype associates with significantly higher HLA-C cell surface expression than does the $-35 T T$ genotype (Figure $4 a$ ). The $-35 C C$ genotype also associates with better control of viral load compared with -35TT in our ART naive seroconverter cohorts (Figure 4b). Thus, high-expression HLA$C$ alleles are in LD with the protective $-35 C$ variant, whereas low-expression alleles are in LD with the susceptible $-35 T$ allele (133). It is not clear why high expression of HLA-C would be protective against HIV, but one obvious possibility is that higher HLA-C expression may enhance antigen presentation to CTLs. Additionally, high HLA-C expression may result in more effective education of $\mathrm{NK}$ cells during their maturation process through better engagement of inhibitory NK receptors to HLA-C ligands, ultimately leading to stronger NK cell responses to $\mathrm{HIV}$-infected target cells.

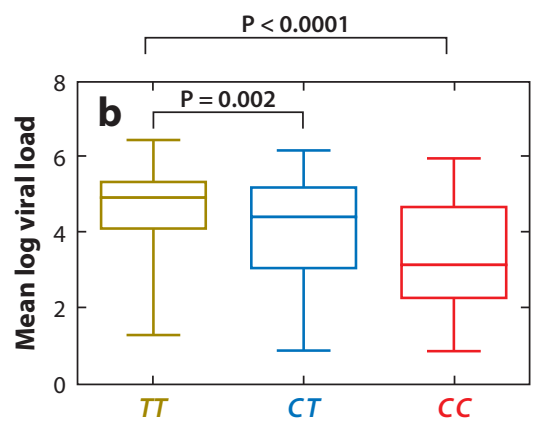

Nef: a nonstructural HIV protein that interferes with multiple cellular pathways including downregulation of class I molecules. The Nef transcript is abundantly expressed immediately after viral integration

Seroconverters: $\mathrm{HIV}$-infected patients for whom date of seroconversion (i.e., appearance of HIV-specific antibodies in serum) can be estimated based on sequential negative and positive test dates

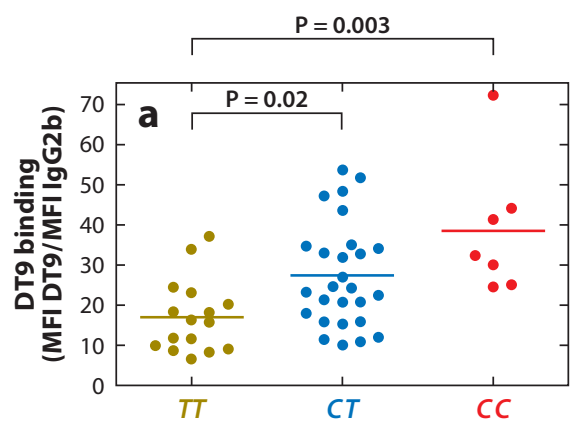

Figure 4

The -35 genotype (TT, $C T$, or $C C$ ) correlates with surface HLA-C expression $(a)$ and mean log viral load $(b)$. HLA-C expression was detected on $\mathrm{CD}^{+}{ }^{+} \mathrm{T}$ lymphocytes of normal individuals by flow cytometry using the DT9 monoclonal antibody and compared between pairs of genotypes. The association of the -35 genotypes with mean log viral load was analyzed in a cohort of $923 \mathrm{HIV}$-1-infected patients. The figure is based on data published previously (133). 
Data now show that high levels of HLA$\mathrm{C}$ expression indeed exert selection pressure on the virus, as HIV-1 Nef variants from $-35 C C$ individuals have an increased ability to impair both class II antigen presentation and helper T cell function to counteract an HLAC-mediated immune response (134). In another recent study of individuals with chronic HIV1 infection, HLA-C-restricted CTL activity accounted for $54 \%$ of the total HIV-specific peptide response, and these CTLs had similar phenotypic characteristics to HLA-A- and -B-restricted CD8 T cells (135). Even though differences between high- and low-expressing HLA-C-specific CTL responses were not investigated, these results are intriguing in the light of the -35 findings. Thus, HLA-C is now a focal consideration in host genetics against HIV and may be an emerging contender for $\mathrm{HIV}$ vaccine design.

\section{HLA Class II}

No strong consistent genetic epidemiological data indicate that variation at the $H L A$ class II loci associates differentially with HIV/AIDS outcomes, although several reports suggest this possibility. Potential involvement of $H L A-D R B$ and $-D Q B$ loci in the risk of infection among African populations have been reported, with some consistent protective effect of $H L A-D R B 1^{*} 01$ and a susceptible effect of $D R B 1^{*} 1503$ (136-138). The $D R B 1^{*} 1301 / 2$ $D Q B 1^{*} 06$ haplotype was associated with viral control after ART interruption, potentially through efficient presentation of a Gag peptide that partially overlaps with the KK10 peptide presented by $\mathrm{B}^{*} 27$ (79). DRB1*1301 carriers were also less likely to transmit virus to their seronegative partners, although the allele had no apparent effect on viral load (138). $D R B 1^{*} 1303$ demonstrates a protective effect on viral load in chronically infected individuals in a South African cohort as well as in a U.S. cohort, but DRB1*1301/02 does not (B. Julg, personal communication).

Specific combinations of class I and class II alleles may interact synergistically, as suggested in a study where $M a m u-B^{*} 17$-positive rhesus monkeys bearing Mamu-DRB1*1003 and $D R B 1^{*} 0306$ controlled SIV significantly better than $M a m u-B^{*} 17$ carriers that did not express these class II alleles (139). Testing combinations of class I and class II alleles for effects in HIV/AIDS is worth pursuing, but the study cohorts would have to be large to have enough power to be conclusive.

\section{KIR POLYMORPHISM IN HIV/AIDS}

Both presence/absence and allelic variation at some of the KIR genes have been implicated in risk of various human diseases and disease outcomes (140). Owing to the functional relationship between HLA class I and KIR loci, an analytical approach that takes into account relevant $K I R$ and $H L A$ genotype combinations has been applied to disease association studies. Strong synergistic effects of $K I R$ and $H L A$ genes/alleles observed in hepatitis C (131) and HIV cohorts $(141,142)$ emphasize the importance of KIRHLA interactions in regulating NK cell activity during viral infections.

\section{KIR3DL1/S1 and HLA-B Bw4 Synergism in AIDS Outcomes}

Analysis of AIDS progression in ART naive seroconverters indicated a protective effect of a compound genotype consisting of KIR3DS1 and Bw4-80I (141) (Figure 5a). This finding was the first to describe an epistatic interaction between KIR and HLA in disease association and indicated the possibility that activating KIR may have biological significance in viral infection. The KIR3DS1/HLA-B Bw4-80I compound genotype was further shown to correlate with lower viral load and protection from opportunistic infections (143). Thus, the genetic data suggested that KIR3DS1 may bind HLAB Bw4-80I ligands on HIV-infected target cells in vivo and that this interaction may delay AIDS progression. In good support of this, Alter et al. (144) demonstrated that NK cells expressing KIR3DS1 strongly inhibit HIV replication 

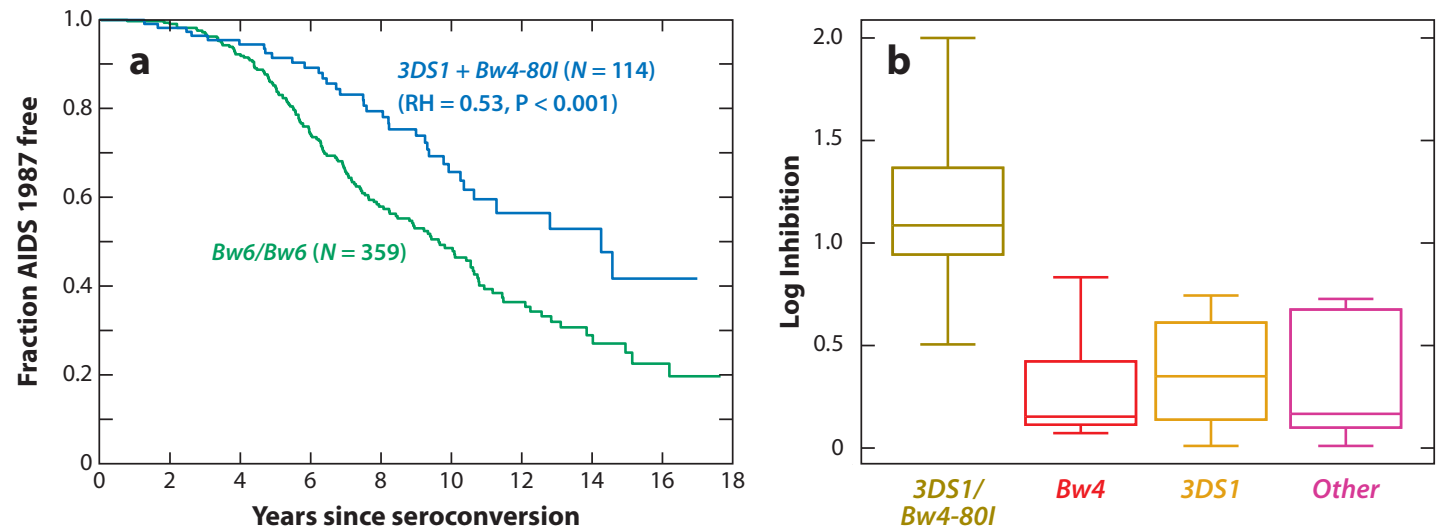

Figure 5

The effect of KIR3DS1 and HLA-B Bw4-80I on HIV infection. (a) Kaplan-Meier survival analysis comparing individuals homozygous for HLA-B Bw6 and individuals with the KIR3DS1/Bw4-80I compound genotype in HIV seroconverters as described in Reference 142 . (b) Inhibition of viral replication by NK cells derived from subjects expressing both KIR3DS1 and Bw4-80I, HLA-B Bw4 and no KIR3DS1, KIR3DS1 and no HLA-B Bw4, and neither KIR3DS1 nor HLA-B Bw4. Inhibition of viral replication in the first groups is significantly higher than in any other group $(\mathrm{p}<0.001)$. The data were presented in Reference 144 .

in target cells expressing HLA-B Bw4-80I compared with KIR3DS1-negative cells (Figure $5 \boldsymbol{b}$ ). However, the synergistic protective effect of KIR3DS1 and $H L A-B$ Bw4-80I was not seen in two other studies $(145,146)$, which may have to do with distinct clinical characteristics of the cohorts, the specific disease outcomes tested, and/or differences in analytical methods. But failure to detect any direct binding of KIR3DS1 to HLA-B Bw4-80I $(147,148)$ is puzzling and leaves open the possibility that other variants in the $M H C$ and KIR loci, which are tracked by KIR3DS1 and/or Bw4-80I through LD, account directly for the protective effect against HIV. Reconciling all these observations must take into account the evidence for selection pressure to maintain KIR3DS1 (149) as well as population genetic data showing a significant inverse correlation in the frequencies of KIR3DS1 and HLA-B Bw4-80I across world populations (Figure 6) (150). No other known or suspected receptor/ligand combinations of KIR and HLA showed a significant correlation in the last study, although an association between KIR2D and a group of $H L A-C$ alleles was observed in a subsequent study (151). The data suggest pressure to maintain a certain low level of the KIR3DS1/HLA-B Bw4-80I combination, which may actually increase risk of some other disease(s).

The effect of KIR3DS1 in combination with $H L A-B$ Bw4-80I implied that activation of NK cells is beneficial in HIV disease. Surprisingly, analysis of inhibitory KIR3DL1 alleles with $H L A-B$ Bw4-80I, suggested that engagement of this receptor is also protective against HIV. The KIR3DL1 allotypes can be divided into those with high expression and high inhibitory capacity, KIR3DL1*h/y, and those with lower expression and lower inhibitory activity, KIR3DL1*1/x (142). Remarkably, the KIR3DL1*b/y + HLA-B Bw4-80I compound genotype demonstrated significant protection from AIDS progression in the same seroconverter cohorts that showed a protective effect of the KIR3DS1/HLA-B Bw4-80I genotype, and it was also associated with lower mean viral loads (141). These data suggest that efficient engagement of both activating and inhibitory KIR is beneficial for the host in viral infection and point to the central significance of the $H L A-B$ locus not only from an acquired immune response perspective but also in terms of innate immunity. The yin-yang situation in which both activating and inhibitory KIR
KIR3DL1 ${ }^{*} h / y$ and KIR3DL $1 * 1 / x$ : groups of KIR3DL1 allotypes distinguished by high or low cell surface expression level and inhibitory capacity $\left({ }^{*} \mathrm{~h}={ }^{*} 001\right.$, *002, *008, *015, $* 009,{ }^{*} 1={ }^{*} 005, * 007$, $\mathrm{y}=* \mathrm{~h}$ or $* 004, \mathrm{x}=$ ${ }^{*} 1,{ }^{*} \mathrm{~h}$, or ${ }^{*} 004$ ) 


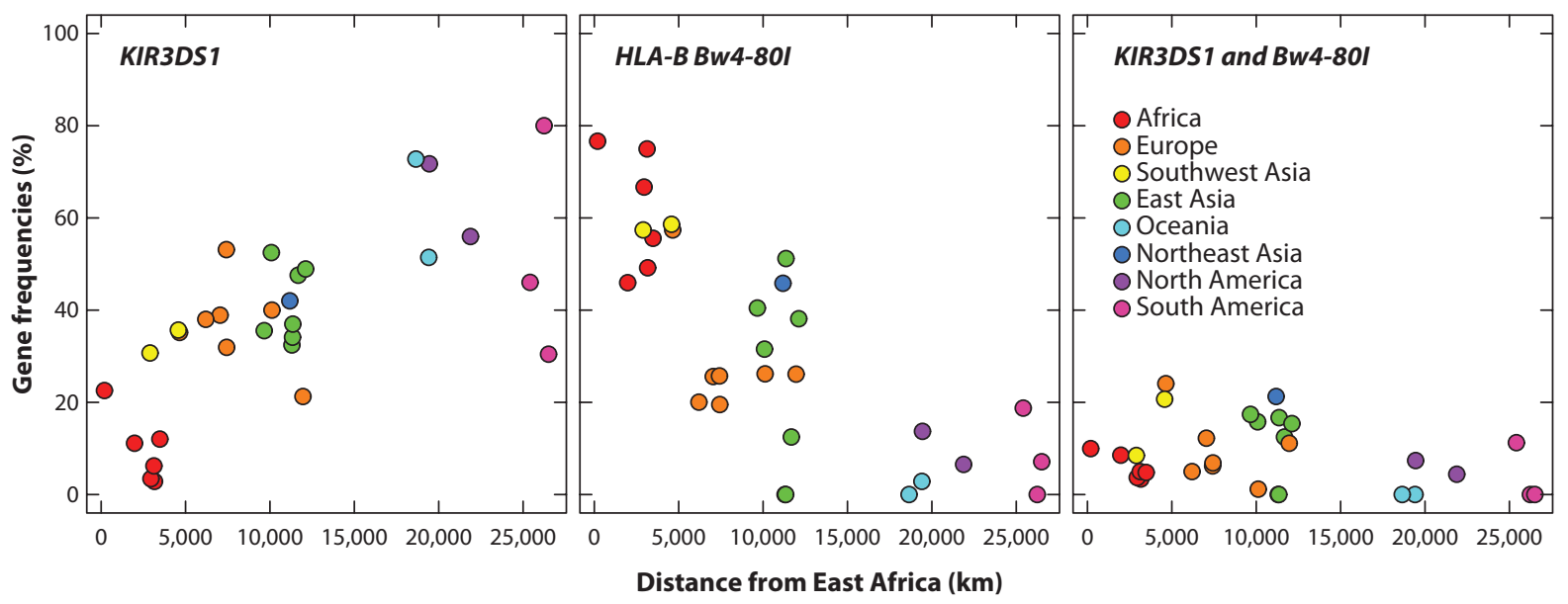

Figure 6

KIR3DS1 and HLA-B Bw4-80I frequencies across populations. Populations are ordered by region based on increasing distance from East Africa. Frequencies of KIR3DS1 increase with the distance from Africa, whereas frequencies of $H L A-B B w 4-80 I$ have the opposite trend. As a result, the frequency of the compound KIR3DS1/Bw4-80I genotype is maintained at an approximately similar low level across populations. The figure is modified from Reference 150 .

alleles confer protection may boil down to protection through NK cell activation. Protection conferred by an activating receptor (KIR3DS1) is intuitively straightforward. Protection by highly inhibitory allotypes (KIR3DL1*h/y) may be attributed to more potent tuning of the high-expressing KIR3DL1-positive NK cells during their maturation process, eventually resulting in stronger activation of those NK cells when their ligand is downregulated (as HLA-B is by HIV Nef).

Notably, the two most protective $H L A-B$ alleles, $B^{*} 57$ and $B^{*} 27$, belong to the $B w 4-80 I$ and Bw4-80T groups, respectively. As is true for all $B w 4$ alleles, the effects of these protective alleles on HIV infection can be mediated by both CD8 T cell and NK cell activity. Indeed, individuals carrying both KIR $3 D L 1^{*} b / y$ and $B^{*} 57$ alleles exhibit the strongest genetic protection both in terms of AIDS progression and viral load in our cohorts (142). Involvement of NK cells in this protection is supported by recent data indicating high functional potential of NK cells isolated from individuals expressing KIR3DL1*h/y and B*57, which might be due to the efficient education of these NK cells (152). $B^{*} 27$, on the other hand, showed greater protection in the presence of KIR3DL1*l/x than in the presence of KIR $3 D L 1^{*} b / y$ (142), which might indicate specificity of low-expression KIR3DL1 allotypes for $\mathrm{B}^{*} 27$.

\section{KIR Genes in Protection From HIV Infection}

Protection from HIV infection in the absence of vaccination is likely to depend on a rapid and efficient innate immune response characteristic of NK cells. Increased NK cell activity was detected in highly exposed uninfected intravenous drug users compared with HIV-infected patients and healthy individuals (153). Within the same cohort, the KIR3DS1/3DL1 transcript ratio was higher among protected individuals (154). The possibility that KIR3DS1 may help protect from HIV infection was supported by a genetic association study that demonstrated a higher frequency of the KIR3DS1 homozygous genotype among exposed HIV-1-negative individuals (155). In a subset of the same cohort, the KIR3DL1*b/y + HLA-B Bw4 $80 I$ genotype was also associated with reduced risk of infection (156), consistent with the effect on 
viral load and disease progression (142). Notably, however, studies of genetic variants that have incomplete penetrance on risk of infection (unlike homozygosity for $C C R 5 \triangle 32$, which provides virtually complete protection from infection) are subject to several problems: poor statistical power due to limited sample sizes, difficulty in identifying individuals who have clearly been exposed repeatedly and remain uninfected, and difficulty in identifying a control group of $\mathrm{HIV}$-infected individuals where selection bias is not an issue. The latter point is subtle and important. In most HIV cohorts, there is a strong possibility that rapid progressors are missing due to frailty bias, thereby artificially increasing the frequency of variants associated with nonprogression and decreasing the frequency of variants associated with rapid progression. Such cohorts do not serve as appropriate controls in studies of exposed uninfected individuals.

\section{CONCLUDING REMARKS}

The outcome of HIV infection in humans is defined by complex interactions between a polymorphic virus and a polymorphic host immune system. Discriminating between cause and effect of an observed immune response to the virus can be problematic when studying these interactions at a given time point. The beauty of genetic epidemiological studies is that they can provide an in vivo population view of factors that affect the host response to the virus differentially across humans, giving meaning in some cases to in vitro functional data. There is a give-and-take situation between genetic and functional studies, where reliable genetic studies depend on confirmation from functional studies. A prime example of mutual support between genetic and functional data in HIV disease involves the HLA loci and their impact on effector cell activity (Table 1). Several groups are now probing combined effects of variation at the HLA and KIR loci through functional assays as a follow-up to some genetic studies, which is important because certain innate immune responses may prevent infection in a natural history setting, and they also embody the critical early control of the virus.

HIV presents an extreme challenge to the human immune system. The virus has

Table 1 HLA class I associations with HIV-1 infection outcomes

\begin{tabular}{|c|c|c|c|}
\hline Genotype & Effect & $\begin{array}{c}\text { GWAS } \\
\text { significance }\end{array}$ & Suggested mechanisms \\
\hline $\begin{array}{l}\text { Heterozygote advantage/rare allele } \\
\text { advantage at } H L A \text { class I }\end{array}$ & Protection & Not applicable & $\begin{array}{l}\text { Broader CTL response }(98,100) \text {; viral escape from } \\
\text { common alleles }(47,101)\end{array}$ \\
\hline$B^{*} 57$ & Protection & Yes & $\begin{array}{l}\text { Immunodominant targeting of multiple conserved Gag } \\
\text { epitopes and reduced viral fitness of escapes }(27-30, \\
\text { 36); cross-reactive nature of epitope restriction }(30, \\
\text { 112); interaction with KIR3DL1/3DS1 }(141,142,152)\end{array}$ \\
\hline$B^{*} 27$ & Protection & No & $\begin{array}{l}\text { Immunodominant targeting of a conserved Gag epitope } \\
\text { and delayed complex escape }(40,111,115,116) ; \\
\text { resistance of epitopes to peptidases (119); interaction } \\
\text { with KIR3DL1 (142) }\end{array}$ \\
\hline $\mathrm{B}^{*} 35-\mathrm{Px}$ & Susceptibility & No & $\begin{array}{l}\text { Peptide binding specificity (3); ILT4-mediated } \\
\text { dysfunction of DCs (127) }\end{array}$ \\
\hline$-35 C C ; H L A-C$ & Protection & Yes & $\begin{array}{l}\text { Efficient CTL or NK cell activity due to high-level } \\
\text { expression of linked } H L A \text {-C alleles (133) }\end{array}$ \\
\hline KIR3DS1+HLA-B Bw4 80I & Protection & Not applicable & $\begin{array}{l}\text { Elevated NK cell cytotoxicity via potential engagement } \\
\text { of KIR3DS1 }(84,141,144)\end{array}$ \\
\hline KIR3DLI*b/y+HLA-B Bw4 80I & Protection & Not applicable & $\begin{array}{l}\text { Elevated NK cell cytotoxicity due to efficient NK cell } \\
\text { education }(142,152)\end{array}$ \\
\hline
\end{tabular}


remarkable genomic flexibility, evolving into the fittest form as dictated by the specific immune system of each individual human host that it infects. The immune systems of some individuals can back the virus into a corner and hold it there, but these people are rare. The precise mechanism(s) for how $\mathrm{B}^{*} 57$ and other immunogenetic variants are capable of forcing the virus to evolve into a form that the host can manage indefinitely needs to be delineated so that this information can be taken into account in the generation of logical vaccines.

\section{DISCLOSURE STATEMENT}

The authors are not aware of any affiliations, memberships, funding, or financial holdings that might be perceived as affecting the objectivity of this review.

\section{ACKNOWLEDGMENTS}

This project has been funded in whole or in part with federal funds from the National Cancer Institute, National Institutes of Health, under Contract No. HHSN261200800001E. The content of this publication does not necessarily reflect the views or policies of the Department of Health and Human Services, nor does mention of trade names, commercial products, or organizations imply endorsement by the U.S. Government. This research was supported in part by the Intramural Research Program of the National Institutes of Health, National Cancer Institute, Center for Cancer Research.

We thank Todd Allen, Colm O'Huigin, and Richard Apps for helpful comments.

\section{LITERATURE CITED}

1. Shiina T, Hosomichi K, Inoko H, Kulski JK. 2009. The HLA genomic loci map: expression, interaction, diversity and disease. 7. Hum. Genet. 54:15-39

2. Marsh SGE, Parham P, Barber LD. 2000. The HLA FactsBook. San Diego: Academic. 398 pp.

3. Gao X, Nelson GW, Karacki P, Martin MP, Phair J, et al. 2001. Effect of a single amino acid change in MHC class I molecules on the rate of progression to AIDS. N. Engl. F. Med. 344:1668-75

4. Vivier E, Tomasello E, Baratin M, Walzer T, Ugolini S. 2008. Functions of natural killer cells. Nat. Immunol. 9:503-10

5. Wilson MJ, Torkar M, Haude A, Milne S, Jones T, et al. 2000. Plasticity in the organization and sequences of human KIR/ILT gene families. Proc. Natl. Acad. Sci. USA 97:4778-83

6. Middleton D, Gonzelez F. 2010. The extensive polymorphism of KIR genes. Immunology 129:8-19

7. Valiante NM, Uhrberg M, Shilling HG, Lienert-Weidenbach K, Arnett KL, et al. 1997. Functionally and structurally distinct NK cell receptor repertoires in the peripheral blood of two human donors. Immunity 7:739-51

8. Carrington M, Martin MP, van Bergen J. 2008. KIR-HLA intercourse in HIV disease. Trends Microbiol. $16: 620-27$

9. Carr WH, Pando MJ, Parham P. 2005. KIR3DL1 polymorphisms that affect NK cell inhibition by HLA-Bw4 ligand. F. Immunol. 175:5222-29

10. Gardiner CM, Guethlein LA, Shilling HG, Pando M, Carr WH, et al. 2001. Different NK cell surface phenotypes defined by the DX9 antibody are due to KIR3DL1 gene polymorphism. F. Immunol. 166:2992-3001

11. Yawata M, Yawata N, Draghi M, Little AM, Partheniou F, Parham P. 2006. Roles for HLA and KIR polymorphisms in natural killer cell repertoire selection and modulation of effector function. f. Exp. Med. 203:633-45 
12. Thomas R, Yamada E, Alter G, Martin MP, Bashirova AA, et al. 2008. Novel KIR3DL1 alleles and their expression levels on NK cells: convergent evolution of KIR3DL1 phenotype variation? F. Immunol. 180:6743-50

13. Jonsson AH, Yokoyama WM. 2009. Natural killer cell tolerance licensing and other mechanisms. Adv. Immunol. 101:27-79

14. Desrosiers MP, Kielczewska A, Loredo-Osti JC, Adam SG, Makrigiannis AP, et al. 2005. Epistasis between mouse Klra and major histocompatibility complex class I loci is associated with a new mechanism of natural killer cell-mediated innate resistance to cytomegalovirus infection. Nat. Genet. 37:593-99

15. Fiebig EW, Wright DJ, Rawal BD, Garrett PE, Schumacher RT, et al. 2003. Dynamics of HIV viremia and antibody seroconversion in plasma donors: implications for diagnosis and staging of primary HIV infection. AIDS 17:1871-79

16. Brenchley JM, Douek DC. 2008. The mucosal barrier and immune activation in HIV pathogenesis. Curr. Opin. HIV AIDS 3:356-61

17. Deeks SG, Walker BD. 2007. Human immunodeficiency virus controllers: mechanisms of durable virus control in the absence of antiretroviral therapy. Immunity 27:406-16

18. Mellors JW, Rinaldo CR Jr, Gupta P, White RM, Todd JA, Kingsley LA. 1996. Prognosis in HIV-1 infection predicted by the quantity of virus in plasma. Science 272:1167-70

19. Rodriguez B, Sethi AK, Cheruvu VK, Mackay W, Bosch RJ, et al. 2006. Predictive value of plasma HIV RNA level on rate of CD4 T-cell decline in untreated HIV infection. 7AMA 296:1498-506

20. Langlade-Demoyen P, Michel F, Hoffenbach A, Vilmer E, Dadaglio G, et al. 1988. Immune recognition of AIDS virus antigens by human and murine cytotoxic T lymphocytes. 7. Immunol. 141:1949-57

21. Walker BD, Chakrabarti S, Moss B, Paradis TJ, Flynn T, et al. 1987. HIV-specific cytotoxic T lymphocytes in seropositive individuals. Nature 328:345-48

22. Walker BD, Flexner C, Paradis TJ, Fuller TC, Hirsch MS, et al. 1988. HIV-1 reverse transcriptase is a target for cytotoxic T lymphocytes in infected individuals. Science 240:64-66

23. Borrow P, Lewicki H, Hahn BH, Shaw GM, Oldstone MB. 1994. Virus-specific CD8 ${ }^{+}$cytotoxic Tlymphocyte activity associated with control of viremia in primary human immunodeficiency virus type 1 infection. 7. Virol. 68:6103-10

24. Koup RA, Safrit JT, Cao Y, Andrews CA, McLeod G, et al. 1994. Temporal association of cellular immune responses with the initial control of viremia in primary human immunodeficiency virus type 1 syndrome. 7. Virol. 68:4650-55

25. Jin X, Bauer DE, Tuttleton SE, Lewin S, Gettie A, et al. 1999. Dramatic rise in plasma viremia after $\mathrm{CD}^{+} \mathrm{T}$ cell depletion in simian immunodeficiency virus-infected macaques. F. Exp. Med. 189:991-98

26. Schmitz JE, Kuroda MJ, Santra S, Sasseville VG, Simon MA, et al. 1999. Control of viremia in simian immunodeficiency virus infection by CD8 ${ }^{+}$lymphocytes. Science 283:857-60

27. Leslie AJ, Pfafferott KJ, Chetty P, Draenert R, Addo MM, et al. 2004. HIV evolution: CTL escape mutation and reversion after transmission. Nat. Med. 10:282-89

28. Brockman MA, Schneidewind A, Lahaie M, Schmidt A, Miura T, et al. 2007. Escape and compensation from early HLA-B57-mediated cytotoxic T-lymphocyte pressure on human immunodeficiency virus type 1 Gag alter capsid interactions with cyclophilin A. F. Virol. 81:12608-18

29. Martinez-Picado J, Prado JG, Fry EE, Pfafferott K, Leslie A, et al. 2006. Fitness cost of escape mutations in p24 Gag in association with control of human immunodeficiency virus type 1. F. Virol. 80:3617-23

30. Miura T, Brockman MA, Schneidewind A, Lobritz M, Pereyra F, et al. 2009. HLA-B57/B*5801 human immunodeficiency virus type 1 elite controllers select for rare Gag variants associated with reduced viral replication capacity and strong cytotoxic T-lymphocyte recognition. 7 . Virol. 83:2743-55

31. Bhattacharya T, Daniels M, Heckerman D, Foley B, Frahm N, et al. 2007. Founder effects in the assessment of HIV polymorphisms and HLA allele associations. Science 315:1583-86

32. Moore CB, John M, James IR, Christiansen FT, Witt CS, Mallal SA. 2002. Evidence of HIV-1 adaptation to HLA-restricted immune responses at a population level. Science 296:1439-43

33. Brumme ZL, Brumme CJ, Heckerman D, Korber BT, Daniels M, et al. 2007. Evidence of differential HLA class I-mediated viral evolution in functional and accessory/regulatory genes of HIV-1. PLoS Pathog. 3:e94
30. Comparative analysis of viral sequences and CTL in B*57/5801-positive EC and viremic subjects. 
43. Characterizes the earliest CTL responses and confirms the major role of CTLs in acute viral control.

\section{Identified the} influence of HLA class I allele frequencies on HIV evolution in populations worldwide.
34. Allen TM, Altfeld M, Geer SC, Kalife ET, Moore C, et al. 2005. Selective escape from CD8 ${ }^{+}$T-cell responses represents a major driving force of human immunodeficiency virus type 1 (HIV-1) sequence diversity and reveals constraints on HIV-1 evolution. 7. Virol. 79:13239-49

35. Borrow P, Lewicki H, Wei X, Horwitz MS, Peffer N, et al. 1997. Antiviral pressure exerted by HIV-1specific cytotoxic T lymphocytes (CTLs) during primary infection demonstrated by rapid selection of CTL escape virus. Nat. Med. 3:205-11

36. Brumme ZL, Brumme CJ, Carlson J, Streeck H, John M, et al. 2008. Marked epitope- and allele-specific differences in rates of mutation in human immunodeficiency type 1 (HIV-1) Gag, Pol, and Nef cytotoxic T-lymphocyte epitopes in acute/early HIV-1 infection. F. Virol. 82:9216-27

37. Cao J, McNevin J, Malhotra U, McElrath MJ. 2003. Evolution of CD8 ${ }^{+} \mathrm{T}$ cell immunity and viral escape following acute HIV-1 infection. 7. Immunol. 171:3837-46

38. Crawford H, Prado JG, Leslie A, Hue S, Honeyborne I, et al. 2007. Compensatory mutation partially restores fitness and delays reversion of escape mutation within the immunodominant HLA-B*5703restricted Gag epitope in chronic human immunodeficiency virus type 1 infection. 7. Virol. 81:8346-51

39. Jones NA, Wei X, Flower DR, Wong M, Michor F, et al. 2004. Determinants of human immunodeficiency virus type 1 escape from the primary $\mathrm{CD}^{+}$cytotoxic $\mathrm{T}$ lymphocyte response. F. Exp. Med. 200:1243-56

40. Kelleher AD, Long C, Holmes EC, Allen RL, Wilson J, et al. 2001. Clustered mutations in HIV-1 gag are consistently required for escape from HLA-B27-restricted cytotoxic T lymphocyte responses. F. Exp. Med. 193:375-86

41. Liu Y, McNevin J, Cao J, Zhao H, Genowati I, et al. 2006. Selection on the human immunodeficiency virus type 1 proteome following primary infection. F. Virol. 80:9519-29

42. Price DA, Goulder PJ, Klenerman P, Sewell AK, Easterbrook PJ, et al. 1997. Positive selection of HIV-1 cytotoxic T lymphocyte escape variants during primary infection. Proc. Natl. Acad. Sci. USA 94:1890-95

43. Goonetilleke N, Liu MK, Salazar-Gonzalez JF, Ferrari G, Giorgi E, et al. 2009. The first T cell response to transmitted/founder virus contributes to the control of acute viremia in HIV-1 infection. F. Exp. Med. 206:1253-72

44. Allen TM, Altfeld M, Yu XG, O'Sullivan KM, Lichterfeld M, et al. 2004. Selection, transmission, and reversion of an antigen-processing cytotoxic $\mathrm{T}$-lymphocyte escape mutation in human immunodeficiency virus type 1 infection. 7. Virol. 78:7069-78

45. Draenert R, Allen TM, Liu Y, Wrin T, Chappey C, et al. 2006. Constraints on HIV-1 evolution and immunodominance revealed in monozygotic adult twins infected with the same virus. 7. Exp. Med. 203:529-39

46. Crawford H, Lumm W, Leslie A, Schaefer M, Boeras D, et al. 2009. Evolution of HLA-B*5703 HIV-1 escape mutations in HLA-B*5703-positive individuals and their transmission recipients. 7. Exp. Med. 206:909-21

47. Kawashima Y, Pfafferott K, Frater J, Matthews P, Payne R, et al. 2009. Adaptation of HIV-1 to human leukocyte antigen class I. Nature 458:641-45

48. Rousseau CM, Daniels MG, Carlson JM, Kadie C, Crawford H, et al. 2008. HLA class I-driven evolution of human immunodeficiency virus type 1 subtype c proteome: immune escape and viral load. F. Virol. 82:6434-46

49. Turnbull EL, Wong M, Wang S, Wei X, Jones NA, et al. 2009. Kinetics of expansion of epitope-specific T cell responses during primary HIV-1 infection. f. Immunol. 182:7131-45

50. Streeck H, Jolin JS, Qi Y, Yassine-Diab B, Johnson RC, et al. 2009. Human immunodeficiency virus type 1-specific $\mathrm{CD} 8^{+} \mathrm{T}$-cell responses during primary infection are major determinants of the viral set point and loss of CD4 ${ }^{+}$T cells. 7. Virol. 83:7641-48

51. Addo MM, Yu XG, Rathod A, Cohen D, Eldridge RL, et al. 2003. Comprehensive epitope analysis of human immunodeficiency virus type $1(\mathrm{HIV}$-1)-specific T-cell responses directed against the entire expressed HIV-1 genome demonstrate broadly directed responses, but no correlation to viral load. 7. Virol. 77:2081-92

52. Masemola A, Mashishi T, Khoury G, Mohube P, Mokgotho P, et al. 2004. Hierarchical targeting of subtype $\mathrm{C}$ human immunodeficiency virus type 1 proteins by $\mathrm{CD} 8^{+} \mathrm{T}$ cells: correlation with viral load. 7. Virol. $78: 3233-43$ 
53. Edwards BH, Bansal A, Sabbaj S, Bakari J, Mulligan MJ, Goepfert PA. 2002. Magnitude of functional $\mathrm{CD}^{+} \mathrm{T}$-cell responses to the Gag protein of human immunodeficiency virus type 1 correlates inversely with viral load in plasma. 7. Virol. 76:2298-305

54. Julg B, Williams KL, Reddy S, Bishop K, Qi Y, et al. 2010. Enhanced anti-HIV functional activity associated with Gag-specific CD8 T-cell responses. F. Virol. 84:5540-49

55. Kiepiela P, Ngumbela K, Thobakgale C, Ramduth D, Honeyborne I, et al. 2007. CD ${ }^{+}$T-cell responses to different HIV proteins have discordant associations with viral load. Nat. Med. 13:46-53

56. Ramduth D, Chetty P, Mngquandaniso NC, Nene N, Harlow JD, et al. 2005. Differential immunogenicity of $\mathrm{HIV}-1$ clade $\mathrm{C}$ proteins in eliciting $\mathrm{CD}^{+}$and $\mathrm{CD}^{+}$cell responses. F. Infect. Dis. 192:1588-96

57. Sacha JB, Chung C, Rakasz EG, Spencer SP, Jonas AK, et al. 2007. Gag-specific CD8 ${ }^{+}$T lymphocytes recognize infected cells before AIDS-virus integration and viral protein expression. F. Immunol. 178:2746-54

58. Betts MR, Nason MC, West SM, De Rosa SC, Migueles SA, et al. 2006. HIV nonprogressors preferentially maintain highly functional HIV-specific CD8 ${ }^{+}$T cells. Blood 107:4781-89

59. Emu B, Sinclair E, Hatano H, Ferre A, Shacklett B, et al. 2008. HLA class I-restricted T-cell responses may contribute to the control of human immunodeficiency virus infection, but such responses are not always necessary for long-term virus control. 7. Virol. 82:5398-407

60. Hersperger AR, Pereyra F, Nason M, Demers K, Sheth P, et al. 2010. Perforin expression directly ex vivo by HIV-specific CD8 T-cells is a correlate of HIV elite control. PLoS Pathog. 6:e1000917

61. Horton H, Frank I, Baydo R, Jalbert E, Penn J, et al. 2006. Preservation of T cell proliferation restricted by protective HLA alleles is critical for immune control of HIV-1 infection. 7. Immunol. 177:7406-15

62. Migueles SA, Laborico AC, Shupert WL, Sabbaghian MS, Rabin R, et al. 2002. HIV-specific CD8 ${ }^{+}$T cell proliferation is coupled to perforin expression and is maintained in nonprogressors. Nat. Immunol. 3:1061-68

63. Saez-Cirion A, Lacabaratz C, Lambotte O, Versmisse P, Urrutia A, et al. 2007. HIV controllers exhibit potent CD8 $\mathrm{T}$ cell capacity to suppress HIV infection ex vivo and peculiar cytotoxic $\mathrm{T}$ lymphocyte activation phenotype. Proc. Natl. Acad. Sci. USA 104:6776-81

64. Janssen EM, Lemmens EE, Wolfe T, Christen U, von Herrath MG, Schoenberger SP. 2003. CD4 ${ }^{+} \mathrm{T}^{\mathrm{T}}$ cells are required for secondary expansion and memory in CD8 ${ }^{+} \mathrm{T}$ lymphocytes. Nature 421:852-56

65. Shedlock DJ, Shen H. 2003. Requirement for CD4 T cell help in generating functional CD8 T cell memory. Science 300:337-39

66. Sun JC, Williams MA, Bevan MJ. 2004. CD4 ${ }^{+}$T cells are required for the maintenance, not programming, of memory $\mathrm{CD}^{+} \mathrm{T}$ cells after acute infection. Nat. Immunol. 5:927-33

67. Douek DC, Brenchley JM, Betts MR, Ambrozak DR, Hill BJ, et al. 2002. HIV preferentially infects HIV-specific CD4+ T cells. Nature 417:95-98

68. McNeil AC, Shupert WL, Iyasere CA, Hallahan CW, Mican JA, et al. 2001. High-level HIV-1 viremia suppresses viral antigen-specific CD4 ${ }^{+}$T cell proliferation. Proc. Natl. Acad. Sci. USA 98:13878-83

69. Palmer BE, Boritz E, Blyveis N, Wilson CC. 2002. Discordance between frequency of human immunodeficiency virus type 1 (HIV-1)-specific gamma interferon-producing CD4 ${ }^{+}$T cells and HIV-1-specific lymphoproliferation in HIV-1-infected subjects with active viral replication. 7. Virol. 76:5925-36

70. Rosenberg ES, Billingsley JM, Caliendo AM, Boswell SL, Sax PE, et al. 1997. Vigorous HIV-1-specific $\mathrm{CD}^{+} \mathrm{T}$ cell responses associated with control of viremia. Science 278:1447-50

71. Boaz MJ, Waters A, Murad S, Easterbrook PJ, Vyakarnam A. 2002. Presence of HIV-1 Gag-specific IFN-gamma ${ }^{+} \mathrm{IL}-2^{+}$and $\mathrm{CD} 28^{+} \mathrm{IL}-2^{+} \mathrm{CD} 4 \mathrm{~T}$ cell responses is associated with nonprogression in $\mathrm{HIV}-1$ infection. F. Immunol. 169:6376-85

72. Appay V, Zaunders JJ, Papagno L, Sutton J, Jaramillo A, et al. 2002. Characterization of CD4+ CTLs ex vivo. F. Immunol. 168:5954-58

73. Norris PJ, Moffett HF, Yang OO, Kaufmann DE, Clark MJ, et al. 2004. Beyond help: direct effector functions of human immunodeficiency virus type 1-specific CD4 ${ }^{+}$T cells. 7 . Virol. 78:8844-51

74. Sacha JB, Giraldo-Vela JP, Buechler MB, Martins MA, Maness NJ, et al. 2009. Gag- and Nef-specific $\mathrm{CD}^{+}{ }^{+} \mathrm{T}$ cells recognize and inhibit SIV replication in infected macrophages early after infection. Proc. Natl. Acad. Sci. USA 106:9791-96 
84. Functional study supporting a role of the $K I R 3 D L 1 / S 1$ and HLA-B Bw4-80I compound genotypes in HIV-1 pathogenesis.

92. The first GWAS demonstrating the primary significance of $H L A$ class I genes in HIV control.
75. Hansen SG, Vieville C, Whizin N, Coyne-Johnson L, Siess DC, et al. 2009. Effector memory T cell responses are associated with protection of rhesus monkeys from mucosal simian immunodeficiency virus challenge. Nat. Med. 15:293-99

76. Rerks-Ngarm S, Pitisuttithum P, Nitayaphan S, Kaewkungwal J, Chiu J, et al. 2009. Vaccination with ALVAC and AIDSVAX to prevent HIV-1 infection in Thailand. N. Engl. F. Med. 361:2209-20

77. McMichael AJ, Kelleher A. 1999. The arrival of HLA class II tetramers. 7. Clin. Investig. 104:1669-70

78. Kaufmann DE, Bailey PM, Sidney J, Wagner B, Norris PJ, et al. 2004. Comprehensive analysis of human immunodeficiency virus type 1 -specific CD4 responses reveals marked immunodominance of gag and nef and the presence of broadly recognized peptides. F. Virol. 78:4463-77

79. Malhotra U, Holte S, Dutta S, Berrey MM, Delpit E, et al. 2001. Role for HLA class II molecules in HIV-1 suppression and cellular immunity following antiretroviral treatment. 7. Clin. Investig. 107:505-17

80. Ramduth D, Day CL, Thobakgale CF, Mkhwanazi NP, de Pierres C, et al. 2009. Immunodominant HIV-1 CD4 ${ }^{+}$T cell epitopes in chronic untreated clade C HIV-1 infection. PLoS ONE 4:e5013

81. Schwartz O, Marechal V, Le Gall S, Lemonnier F, Heard JM. 1996. Endocytosis of major histocompatibility complex class I molecules is induced by the HIV-1 Nef protein. Nat. Med. 2:338-42

82. Cohen GB, Gandhi RT, Davis DM, Mandelboim O, Chen BK, et al. 1999. The selective downregulation of class I major histocompatibility complex proteins by HIV-1 protects HIV-infected cells from NK cells. Immunity 10:661-71

83. Alter G, Teigen N, Ahern R, Streeck H, Meier A, et al. 2007. Evolution of innate and adaptive effector cell functions during acute HIV-1 infection. F. Infect. Dis. 195:1452-60

84. Alter G, Rihn S, Walter K, Nolting A, Martin M, et al. 2009. HLA class I subtype-dependent expansion of KIR3DS1 ${ }^{+}$and $\mathrm{KIR} \mathrm{DL} 1^{+} \mathrm{NK}$ cells during acute human immunodeficiency virus type 1 infection. F. Virol. 83:6798-805

85. Bonaparte MI, Barker E. 2003. Inability of natural killer cells to destroy autologous HIV-infected T lymphocytes. AIDS 17:487-94

86. Mavilio D, Benjamin J, Daucher M, Lombardo G, Kottilil S, et al. 2003. Natural killer cells in HIV-1 infection: dichotomous effects of viremia on inhibitory and activating receptors and their functional correlates. Proc. Natl. Acad. Sci. USA 100:15011-16

87. Ullum H, Gotzsche PC, Victor J, Dickmeiss E, Skinhoj P, Pedersen BK. 1995. Defective natural immunity: an early manifestation of human immunodeficiency virus infection. F. Exp. Med. 182:789-99

88. Mavilio D, Lombardo G, Benjamin J, Kim D, Follman D, et al. 2005. Characterization of CD56 ${ }^{-} / \mathrm{CD} 6^{+}$ natural killer (NK) cells: a highly dysfunctional NK subset expanded in HIV-infected viremic individuals. Proc. Natl. Acad. Sci. USA 102:2886-91

89. Alter G, Teigen N, Davis BT, Addo MM, Suscovich TJ, et al. 2005. Sequential deregulation of NK cell subset distribution and function starting in acute HIV-1 infection. Blood 106:3366-69

90. Dalmasso C, Carpentier W, Meyer L, Rouzioux C, Goujard C, et al. 2008. Distinct genetic loci control plasma HIV-RNA and cellular HIV-DNA levels in HIV-1 infection: the ANRS Genome Wide Association 01 study. PLoS ONE 3:e3907

91. Fellay J, Ge D, Shianna KV, Colombo S, Ledergerber B, et al. 2009. Common genetic variation and the control of HIV-1 in humans. PLoS Genet. 5:e1000791

92. Fellay J, Shianna KV, Ge D, Colombo S, Ledergerber B, et al. 2007. A whole-genome association study of major determinants for host control of HIV-1. Science 317:944-47

93. Pelak K, Goldstein DB, Walley NM, Fellay J, Ge D, et al. 2010. Host determinants of HIV-1 control in African Americans. F. Infect. Dis. 201:1141-49

94. Limou S, Le Clerc S, Coulonges C, Carpentier W, Dina C, et al. 2009. Genomewide association study of an AIDS-nonprogression cohort emphasizes the role played by HLA genes (ANRS Genomewide Association Study 02). F. Infect. Dis. 199:419-26

95. Satta Y, O'HUigin C, Takahata N, Klein J. 1993. The synonymous substitution rate of the major histocompatibility complex loci in primates. Proc. Natl. Acad. Sci. USA 90:7480-84

96. Klein J, O’Huigin C. 1994. MHC polymorphism and parasites. Philos. Trans. R. Soc. Lond. B Biol. Sci. 346:351-57; discussion 7-8

97. Borghans JA, Beltman JB, De Boer RJ. 2004. MHC polymorphism under host-pathogen coevolution. Immunogenetics 55:732-39 
98. Carrington M, Nelson GW, Martin MP, Kissner T, Vlahov D, et al. 1999. HLA and HIV-1: heterozygote advantage and B*35-Cw*04 disadvantage. Science 283:1748-52

99. Tang J, Costello C, Keet IP, Rivers C, Leblanc S, et al. 1999. HLA class I homozygosity accelerates disease progression in human immunodeficiency virus type 1 infection. AIDS Res. Hum. Retrovir. 15:31724

100. O'Connor SL, Lhost JJ, Becker EA, Detmer AM, Johnson RC, et al. 2010. MHC heterozygote advantage in simian immunodeficiency virus-infected Mauritian cynomolgus macaques. Sci. Transl. Med. 2:22ra18

101. Trachtenberg E, Korber B, Sollars C, Kepler TB, Hraber PT, et al. 2003. Advantage of rare HLA supertype in HIV disease progression. Nat. Med. 9:928-35

102. Marsh SG, Albert ED, Bodmer WF, Bontrop RE, Dupont B, et al. 2010. Nomenclature for factors of the HLA system, 2010. Tissue Antigens 75:291-455

103. Martin MP, Carrington M. 2005. Immunogenetics of viral infections. Curr. Opin. Immunol. 17:510-16

104. Kiepiela P, Leslie AJ, Honeyborne I, Ramduth D, Thobakgale C, et al. 2004. Dominant influence of HLA-B in mediating the potential co-evolution of HIV and HLA. Nature 432:769-75

105. Migueles SA, Sabbaghian MS, Shupert WL, Bettinotti MP, Marincola FM, et al. 2000. HLA B*5701 is highly associated with restriction of virus replication in a subgroup of HIV-infected long term nonprogressors. Proc. Natl. Acad. Sci. USA 97:2709-14

106. Gao X, Bashirova A, Iversen AK, Phair J, Goedert JJ, et al. 2005. AIDS restriction HLA allotypes target distinct intervals of HIV-1 pathogenesis. Nat. Med. 11:1290-92

107. Kaslow RA, Carrington M, Apple R, Park L, Munoz A, et al. 1996. Influence of combinations of human major histocompatibility complex genes on the course of HIV-1 infection. Nat. Med. 2:405-11

108. Pereyra F, Addo MM, Kaufmann DE, Liu Y, Miura T, et al. 2008. Genetic and immunologic heterogeneity among persons who control HIV infection in the absence of therapy. F. Infect. Dis. 197:563-71

109. Altfeld M, Addo MM, Rosenberg ES, Hecht FM, Lee PK, et al. 2003. Influence of HLA-B57 on clinical presentation and viral control during acute HIV-1 infection. AIDS 17:2581-91

110. Migueles SA, Laborico AC, Imamichi H, Shupert WL, Royce C, et al. 2003. The differential ability of HLA B* $5701^{+}$long-term nonprogressors and progressors to restrict human immunodeficiency virus replication is not caused by loss of recognition of autologous viral gag sequences. F. Virol. 77:6889-98

111. Altfeld M, Kalife ET, Qi Y, Streeck H, Lichterfeld M, et al. 2006. HLA alleles associated with delayed progression to AIDS contribute strongly to the initial $\mathrm{CD8}^{+} \mathrm{T}$ cell response against HIV-1. PLoS Med. 3:e403

112. Kosmrlj A, Read EL, Qi Y, Allen TM, Altfeld M, et al. 2010. Effects of thymic selection of the T-cell repertoire on HLA class I-associated control of HIV infection. Nature 465:350-54

113. Hendel H, Caillat-Zucman S, Lebuanec H, Carrington M, O’Brien S, et al. 1999. New class I and II HLA alleles strongly associated with opposite patterns of progression to AIDS. F. Immunol. 162:6942-46

114. Magierowska M, Theodorou I, Debre P, Sanson F, Autran B, et al. 1999. Combined genotypes of CCR5, CCR2, SDF1, and HLA genes can predict the long-term nonprogressor status in human immunodeficiency virus-1-infected individuals. Blood 93:936-41

115. Goulder PJ, Phillips RE, Colbert RA, McAdam S, Ogg G, et al. 1997. Late escape from an immunodominant cytotoxic T-lymphocyte response associated with progression to AIDS. Nat. Med. 3:212-17

116. Schneidewind A, Brockman MA, Yang R, Adam RI, Li B, et al. 2007. Escape from the dominant HLAB27-restricted cytotoxic T-lymphocyte response in Gag is associated with a dramatic reduction in human immunodeficiency virus type 1 replication. F. Virol. 81:12382-93

117. Feeney ME, Tang Y, Roosevelt KA, Leslie AJ, McIntosh K, et al. 2004. Immune escape precedes breakthrough human immunodeficiency virus type 1 viremia and broadening of the cytotoxic T-lymphocyte response in an HLA-B27-positive long-term-nonprogressing child. f. Virol. 78:8927-30

118. Schneidewind A, Brumme ZL, Brumme CJ, Power KA, Reyor LL, et al. 2009. Transmission and longterm stability of compensated CD8 escape mutations. 7. Virol. 83:3993-97

119. Loffredo JT, Sidney J, Bean AT, Beal DR, Bardet W, et al. 2009. Two MHC class I molecules associated with elite control of immunodeficiency virus replication, Mamu-B*08 and HLA-B*2705, bind peptides with sequence similarity. F. Immunol. 182:7763-75
100. This study provides the strongest support for MHC heterozygote advantage in viral infection.

111. Shows that protective HLA class I alleles have a greater contribution to the total CTL response.

112. A theoretical approach to explain the effect of HLA class I allotypes in response to HIV. 
133. Implicates a role of HLA-C in HIV disease pathogenesis.

142. Shows a protective effect of highexpressing KIR3DL1 alleles in combination with $H L A-B$ Bw4-80I in HIV-positive subjects.
120. Itescu S, Mathur-Wagh U, Skovron ML, Brancato LJ, Marmor M, et al. 1992. HLA-B35 is associated with accelerated progression to AIDS. 7. Acquir. Immune Defic. Syndr. 5:37-45

121. Sahmoud T, Laurian Y, Gazengel C, Sultan Y, Gautreau C, Costagliola D. 1993. Progression to AIDS in French haemophiliacs: association with HLA-B35. AIDS 7:497-500

122. Scorza Smeraldi R, Fabio G, Lazzarin A, Eisera NB, Moroni M, Zanussi C. 1986. HLA-associated susceptibility to acquired immunodeficiency syndrome in Italian patients with human-immunodeficiency-virus infection. Lancet 2:1187-89

123. Streeck H, Lichterfeld M, Alter G, Meier A, Teigen N, et al. 2007. Recognition of a defined region within p24 Gag by CD8 ${ }^{+} \mathrm{T}$ cells during primary human immunodeficiency virus type 1 infection in individuals expressing protective HLA class I alleles. 7. Virol. 81:7725-31

124. Steinle A, Falk K, Rotzschke O, Gnau V, Stevanovic S, et al. 1996. Motif of HLA-B*3503 peptide ligands. Immunogenetics 43:105-7

125. Smith KJ, Reid SW, Stuart DI, McMichael AJ, Jones EY, Bell JI. 1996. An altered position of the alpha 2 helix of MHC class I is revealed by the crystal structure of HLA-B*3501. Immunity 4:203-13

126. Hill AV, Elvin J, Willis AC, Aidoo M, Allsopp CE, et al. 1992. Molecular analysis of the association of HLA-B53 and resistance to severe malaria. Nature 360:434-39

127. Huang J, Goedert JJ, Sundberg EJ, Cung TD, Burke PS, et al. 2009. HLA-B*35-Px-mediated acceleration of HIV-1 infection by increased inhibitory immunoregulatory impulses. 7. Exp. Med. 206:2959-66

128. Jin X, Gao X, Ramanathan M Jr, Deschenes GR, Nelson GW, et al. 2002. Human immunodeficiency virus type 1 (HIV-1)-specific $\mathrm{CD}^{+}-\mathrm{T}$-cell responses for groups of $\mathrm{HIV}$-1-infected individuals with different HLA-B*35 genotypes. F. Virol. 76:12603-10

129. Snary D, Barnstable CJ, Bodmer WF, Crumpton MJ. 1977. Molecular structure of human histocompatibility antigens: the HLA-C series. Eur 7. Immunol. 7:580-85

130. Bashirova AA, Martin MP, McVicar DW, Carrington M. 2006. The killer immunoglobulin-like receptor gene cluster: tuning the genome for defense. Annu. Rev. Genomics Hum. Genet. 7:277-300

131. Khakoo SI, Thio CL, Martin MP, Brooks CR, Gao X, et al. 2004. HLA and NK cell inhibitory receptor genes in resolving hepatitis $\mathrm{C}$ virus infection. Science 305:872-74

132. Stranger BE, Forrest MS, Clark AG, Minichiello MJ, Deutsch S, et al. 2005. Genome-wide associations of gene expression variation in humans. PLoS Genet. 1:e78

133. Thomas R, Apps R, Qi Y, Gao X, Male V, et al. 2009. HLA-C cell surface expression and control of HIV/AIDS correlate with a variant upstream of HLA-C. Nat. Genet. 41:1290-94

134. Specht A, Telenti A, Martinez R, Fellay J, Bailes E, et al. 2010. Counteraction of HLA-C-mediated immune control of HIV-1 by Nef. F. Virol. 84:7300-11

135. Makadzange AT, Gillespie G, Dong T, Kiama P, Bwayo J, et al. 2010. Characterization of an HLA-Crestricted CTL response in chronic HIV infection. Eur. 7. Immunol. 40:1036-41

136. Lacap PA, Huntington JD, Luo M, Nagelkerke NJ, Bielawny T, et al. 2008. Associations of human leukocyte antigen DRB with resistance or susceptibility to HIV-1 infection in the Pumwani Sex Worker Cohort. AIDS 22:1029-38

137. Ndung'u T, Gaseitsiwe S, Sepako E, Doualla-Bell F, Peter T, et al. 2005. Major histocompatibility complex class II (HLA-DRB and -DQB) allele frequencies in Botswana: association with human immunodeficiency virus type 1 infection. Clin. Diagn. Lab. Immunol. 12:1020-28

138. Tang J, Penman-Aguilar A, Lobashevsky E, Allen S, Kaslow RA. 2004. HLA-DRB1 and -DQB1 alleles and haplotypes in Zambian couples and their associations with heterosexual transmission of HIV type 1. 7. Infect. Dis. 189:1696-704

139. Giraldo-Vela JP, Rudersdorf R, Chung C, Qi Y, Wallace LT, et al. 2008. The major histocompatibility complex class II alleles Mamu-DRB1*1003 and -DRB1*0306 are enriched in a cohort of simian immunodeficiency virus-infected rhesus macaque elite controllers. F. Virol. 82:859-70

140. Kulkarni S, Martin MP, Carrington M. 2008. The Yin and Yang of HLA and KIR in human disease. Semin. Immunol. 20:343-52

141. Martin MP, Gao X, Lee JH, Nelson GW, Detels R, et al. 2002. Epistatic interaction between KIR3DS1 and HLA-B delays the progression to AIDS. Nat. Genet. 31:429-34

142. Martin MP, Qi Y, Gao X, Yamada E, Martin JN, et al. 2007. Innate partnership of HLA-B and KIR3DL1 subtypes against HIV-1. Nat. Genet. 39:733-40 
143. Qi Y, Martin MP, Gao X, Jacobson L, Goedert JJ, et al. 2006. KIR/HLA pleiotropism: protection against both HIV and opportunistic infections. PLoS Pathog. 2:e79

144. Alter G, Martin MP, Teigen N, Carr WH, Suscovich TJ, et al. 2007. Differential natural killer cellmediated inhibition of HIV-1 replication based on distinct KIR/HLA subtypes. F. Exp. Med. 204:3027-36

145. Barbour JD, Sriram U, Caillier SJ, Levy JA, Hecht FM, Oksenberg JR. 2007. Synergy or independence? Deciphering the interaction of HLA class I and NK cell KIR alleles in early HIV-1 disease progression. PLoS Pathog. 3:e43

146. Gaudieri S, DeSantis D, McKinnon E, Moore C, Nolan D, et al. 2005. Killer immunoglobulin-like receptors and HLA act both independently and synergistically to modify HIV disease progression. Genes Immun. 6:683-90

147. Carr WH, Rosen DB, Arase H, Nixon DF, Michaelsson J, Lanier LL. 2007. Cutting edge: KIR3DS1, a gene implicated in resistance to progression to AIDS, encodes a DAP12-associated receptor expressed on NK cells that triggers NK cell activation. F. Immunol. 178:647-51

148. O'Connor GM, Guinan KJ, Cunningham RT, Middleton D, Parham P, Gardiner CM. 2007. Functional polymorphism of the KIR3DL1/S1 receptor on human NK cells. F. Immunol. 178:235-41

149. Norman PJ, Abi-Rached L, Gendzekhadze K, Korbel D, Gleimer M, et al. 2007. Unusual selection on the KIR3DL1/S1 natural killer cell receptor in Africans. Nat. Genet. 39:1092-99

150. Single RM, Martin MP, Gao X, Meyer D, Yeager M, et al. 2007. Global diversity and evidence for coevolution of KIR and HLA. Nat. Genet. 39:1114-19

151. Hollenbach JA, Meenagh A, Sleator C, Alaez C, Bengoche M, et al. 2010. Report from the killer immunoglobulin-like receptor (KIR) anthropology component of the 15th International Histocompatibility Workshop: worldwide variation in the KIR loci and further evidence for the co-evolution of KIR and HLA. Tissue Antigens 76:9-17

152. Boulet S, Song R, Kamya P, Bruneau J, Shoukry NH, et al. 2010. HIV protective KIR3DL1 and HLA$B$ genotypes influence NK cell function following stimulation with HLA-devoid cells. F. Immunol. 184:2057-64

153. Scott-Algara D, Truong LX, Versmisse P, David A, Luong TT, et al. 2003. Cutting edge: increased NK cell activity in HIV-1-exposed but uninfected Vietnamese intravascular drug users. 7. Immunol. 171:5663-67

154. Ravet S, Scott-Algara D, Bonnet E, Tran HK, Tran T, et al. 2007. Distinctive NK-cell receptor repertoires sustain high-level constitutive NK-cell activation in HIV-exposed uninfected individuals. Blood 109:4296-305

155. Boulet S, Sharafi S, Simic N, Bruneau J, Routy JP, et al. 2008. Increased proportion of KIR3DS1 homozygotes in HIV-exposed uninfected individuals. AIDS 22:595-99

156. Boulet S, Kleyman M, Kim JY, Kamya P, Sharafi S, et al. 2008. A combined genotype of KIR3DL1 high expressing alleles and HLA-B*57 is associated with a reduced risk of HIV infection. AIDS 22:1487-91 


\section{Erratum:}

Figure $4 \mathrm{~b}$ was changed from the original such that the y-axis label runs from 0 to 8 , rather than from 0 to 70 .

This erratum was posted online on May 6, 2011. 